\title{
Stature and Stature Distribution in Portuguese Male Adults 1904-1998: The Role of Environmental Factors
}

\author{
CRISTINA PADEZ* \\ Departamento de Antropologia, Universidade de Coimbra, 3000-056 Coimbra, Portugal
}

\begin{abstract}
The records of height of 841,457 18-year-old Portuguese males were analyzed by area of residence (districts). The sample included all Portuguese 18-year-old males born between 1966 and 1979 and examined between 1985 and 1998, in the north, center, and south of Portugal. They represent all social strata. There were statistically significant differences $(P \leq 0.001)$ among districts: males from Lisbon $(172.8 \mathrm{~cm})$ and Setúbal $(172.7 \mathrm{~cm})$, the most developed districts, were tallest, and those from Madeira $(169.7 \mathrm{~cm})$ and Coimbra $(171.6 \mathrm{~cm})$ were shortest. Compared with published data for 1904, there was a positive secular trend in height. The average increase was $8.93 \mathrm{~cm}$ and the estimated rate was $0.99 \mathrm{~cm}$ per decade. The changes that occurred were mainly the result of the reduction of the shortest classes of stature, those $<150 \mathrm{~cm}$ to $170 \mathrm{~cm}$, and an increase in the frequency of the highest classes, $\geq 170 \mathrm{~cm}$. This positive trend and the changes in stature distribution must be related to the general improvement in standard living conditions that occurred in Portugal primarily after the 1960s and 1970s, especially in terms of nutrition and the health system. Taking into account the socioeconomic differences that still exist between districts, the results suggest that the secular trend in height should continue for the Portuguese population in future decades. Am. J. Hum. Biol. 14:39-49, 2002. (c) 2002 Wiley-Liss, Inc.
\end{abstract}

Since the end of the 19 th century, a positive secular trend towards a taller adult stature has been observed in almost every country in Europe, North America, and Japan. Human adult height represents the end product of a continuous and often nonadditive interaction between genetic and environmental forces (Tanner, 1992). The most important environmental factors to influence secular trends are nutrition and health (Malina, 1979). Indirect factors affecting nutrition (both qualitatively and quantitatively) and health are alterations in socioeconomic living conditions, social and health care (preventive and curative), minimum income, quality of food preparation, better sanitary conditions, mass vaccination, and level of education (Tanner, 1992; Bodzsár and Susanne, 1998; Hauspie et al., 1996; van Wieringen, 1986). Growth of a population can, therefore, be used as a "mirror of conditions in society" (Tanner, 1986). In recent years, economic historians, led by Fogel et al. (1982), have used data on the heights of various populations over the last 150 years to trace their economic fortunes and even to predict trends in mortality and morbidity. Adult height is a predictor of mortality from coronary heart disease and, to a lesser extent, other diseases (Barker et al., 1990; Waaler, 1984). Some research suggest that environmental influences during childhood underlie adult differences between population subgroups (Nystrom Peck and Lundber, 1995).

Adult height reached a plateau during the mid-1980s in some developed European countries, which suggests that they are perhaps near their genetic potential or that social conditions have ceased to improve. In the European countries the secular trend is more marked among the lower social classes (Susanne and Heyne, 1972; Low et al., 1981, 1982; Laska-Mierzejewska, et al., 1982; Chinn et al., 1989; Vercauteren and Slachmuylder, 1993). In some lesser-developed European nations, an increase is still occurring (Bielicki et al., 1992; Hauspie et al., 1996; Schmidt et al., 1995).

Despite the large amount of work concerning the secular trend, investigation of stature has largely been limited to the study of changes in means through time, whereas changes in stature distributions have been regarded as less impressive. Few works on secular trend can analyze stature distribution like those published by Hermanussen

*Correspondence to: C. Padez, Departamento de Antropologia, Universidade de Coimbra, 3000-056 Coimbra, Portugal. E-mail: cpadez@ci.uc.pt

Received 14 March; Revision received 24 July 2001; Accepted 25 July 2001 
et al. (1995) on West German, Italian, and Dutch conscripts, two studies on the Spanish population (Carrion, 1986; Hernández and García-Moro, 1986), two on the French population (Chamla, 1983; Pineau, 1993), and the work of van Wieringen (1986) in The Netherlands.

The aim of the present study is to examine how social and economic changes in Portugal during the 20th century relate to changes in adult height and height distribution between 1904 and 1998 in a sample of 18-year-old male Portuguese. Regional differences from 1904 to 1998 are also analyzed.

\section{SOCIAL CHANGES IN PORTUGAL}

Contrary to many other European countries, which experienced important social and economic changes after World War II, the general improvement in the living conditions of the Portuguese population occurred later during the 1960s. At this time, from the demographic point of view, Portugal was a very different country in Europe. It had the highest proportion of young people ( $<15$ years), the lowest proportion of old people (>65 years), the lowest life expectancy at birth, the highest rate of natality, and the highest rate of infant mortality. After 40 years, these values are very different. Portugal is now the country with the lowest population growth rate, and the proportions of young and old people are now similar to other European countries. Life expectancy at birth is still one of the lowest but close to the average European values, the birth rate is similar to the European mean, and infant mortality is also similar to other European countries (Barreto, 1996, 2000).

However, there are some specific factors in the social and economic evolution of the Portuguese population. The first is the rate of external emigration to Europe, especially to France, and the rate of internal migration from the countryside to cities, especially to Lisbon and Porto. In 1990, almost $40 \%$ of the Portuguese population live in the Lisbon and Porto areas (Barreto, 1996, 2000).

The industrial sector also showed an acceleration in the decade of the 1960s. But, contrary to all the other European countries, the services were more important in the economic sector and not the industrial sector. An indirect consequence of these major changes in social and economic structures was a global improvement of living conditions during the past 40 years.

\section{MATERIALS AND METHODS}

\section{Sample}

Data were obtained from the records of medical examination at District Recruiting Centers of Portugal (North, Center, and South). Military service is compulsory in Portugal. The entire cohort of males born in a given year is examined by military physicians during a registration visit lasting 3 days. Height was measured to the nearest centimeter during the medical examination. The sample thus represents all regions of the country and all social strata (Fig. 1).

The sample included all Portuguese 18year-old males born between 1966 and 1979 and examined between 1985 and 1998 (841,457 subjects). Data published by Lacerda (1904) for all districts of Portugal and data published by Sobral (1990) for the years 1930 to 1980 just for the South of Portugal (Districts of Lisboa, Setúbal, Évora, and Beja) were also considered.

\section{Social data}

Locality of each subject's residence by district (i.e., administrative region) was also obtained. In Portugal there are 20 districts. Two of them (Açores and Madeira) are islands located in the Atlantic Ocean (Fig. 1).

\section{Vital statistics}

Data concerning demography, health, economy, nutrition, and house conditions between 1920 and 1990 were collected from statistical yearbooks published of the $\mathrm{Na}$ tional Institute of Statistics (INE). For same variables, e.g., house conditions, data are available only after 1960. The following demographic and health indicators were recorded: birth rate; age distribution; infant and post-neonatal mortality rates; life expectancy; adult literacy; number of physicians per 1,000 population; maternal mortality; and born at the maternity hospital (\%). The following economic and housing conditions were recorded: distribution of the population in the three economic 


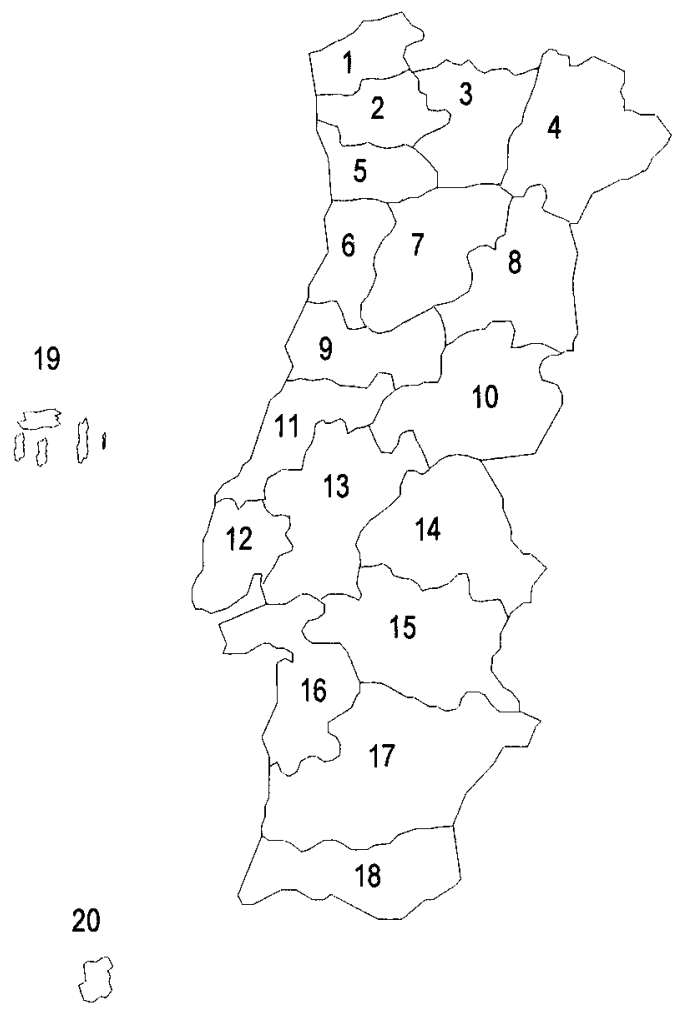

Fig. 1. Districts of Portugal: 1, V. Castelo; 2, Braga; 3, V. Real; 4, Bragança; 5, Porto; 6, Aveiro; 7, Viseu; 8, Guarda; 9, Coimbra; 10, C. Branco; 11, Leiria; 12, Lis boa; 13, Santarém; 14, Portalegre; 15, Évora; 16, Setúbal; 17, Beja; 18, Faro; 19, Açores; 20, Madeira.

sectors (agricultural, industry, and services); tap water; shower and bathing tub; sanitary equipment; and sewerage systems. Data concerning total daily energy intake (calories/day) of some products between 1963 and 1997 and the program of milk supply in elementary schools were also considered.

\section{Statistical analysis}

One way analysis of variance for height and locality of subject residence (20 districts) was done. The following intervals were considered for stature distributions: $<145 \mathrm{~cm}, 145-150 \mathrm{~cm}, 150-155 \mathrm{~cm}, 155-$ $160 \mathrm{~cm}, 160-165 \mathrm{~cm}, 165-170 \mathrm{~cm}, 170-175$ $\mathrm{cm}, 175-180$, and $\geq 180 \mathrm{~cm}$. The Kolmogorov- Smirnov test was used to analyze nor- mality of distributions of heights for each year.

\section{RESULTS}

\section{Sociodemographic and health characteristics}

Table 1 summarizes the evolution of several socio-demographic and health indicators in Portugal during the 20th century. Birth rates decreased sharply from 1920 (33.6) to 1990 (11.6). The age distribution showed a decrease in the percentage of young people ( $<15$ years), from $32.6 \%$ in 1920 to $20 \%$ in 1990 . At the same time, the percentage of old people increased from $5.9 \%$ in 1920 to $13.6 \%$ in 1990 . Infant mortality and post-neonatal mortality rates both decreased, and life expectancy increase from 35.8 years in men and 40 years in women in 1920 to 70.3 and 77.5 years in 1990 for men and women, respectively. Adult literacy increased from $34.6 \%$ in 1920 to $89 \%$ in 1990 .

The health system of Portugal also showed major changes. The number of physicians per 1,000 population increased from 352 to 1256 between 1960 and 1990 . Maternal mortality decreased, from 115.5 in 1960 to 10.3 in 1990, and the percentage of newborns that was delivered at a hospital increased from $18.4 \%$ in 1960 to $95.5 \%$ in 1990.

In the economic sector, the agricultural system decreased from $48.2 \%$ in 1930 to $10.6 \%$ in 1990, whereas the industrial and service sectors both increased, especially the industrial sector.

From 1960 to 1990 the percentage of houses with tap water changed from $28.9 \%$ to $86.8 \%$, and those with a shower and bathing tub increased from $18.6 \%$ to $81.8 \%$. Homes with sanitary equipment (indoor toilets) increased from $41.8 \%$ to $88.5 \%$. Homes with electricity increased from $40.5 \%$ to $97.7 \%$. Finally, sewerage systems were present just in $38.3 \%$ of houses in 1960 and $90.7 \%$ in 1990

Table 2 presents the per capita total daily energy intake of some products in Portugal. From the 1960s to the 1990s, the consumption of several products increased, including milk (76-237 cal/day), meat (78-328 cal/ day), fats (407-788 cal/day), sugar (209-350 cal/day), eggs (14-30 cal/ day), and alcohol (172-196 cal/day). The consumption of calories increased from 2,671 to 3,577 between 1960 and 1990 . 
TABLE 1. Evolution of some socio-demographic and health indicators in Portugal between 1920 and $1990^{*}$

\begin{tabular}{|c|c|c|c|c|c|c|c|c|}
\hline Demography & 1920 & 1930 & 1940 & 1950 & 1960 & 1970 & 1980 & 1990 \\
\hline Birth rate ${ }^{1}$ & 33.6 & 29.7 & 24.3 & 24.3 & 24.1 & 20.9 & 16.13 & 11.8 \\
\hline Age group $<15$ years $(\%)$ & 32.6 & 31.9 & 31.8 & 29.2 & 29.2 & 28.5 & 25.5 & 20 \\
\hline Age group $\geq 65$ years $(\%)$ & 5.9 & 6.2 & 6.4 & 6.9 & 8 & 9.7 & 11.5 & 13.6 \\
\hline Fecundity Index ${ }^{2}$ & - & 3.9 & 3.2 & 3.2 & 3.2 & 3 & 2.2 & 1.5 \\
\hline Infant mortality rate ${ }^{3}$ & 177 & 144 & 126 & 94.1 & 77.5 & 55.5 & 21.8 & 10.8 \\
\hline Post-neonatal mortality rate ${ }^{4}$ & - & 95.5 & 87.5 & 62.9 & 46.77 & 31.86 & 10.46 & 3.34 \\
\hline Life expectancy - men (years) & 35.8 & 44.8 & 48.6 & 55.5 & 60.7 & 64.2 & 69.3 & 70.3 \\
\hline Life expectancy - women (years) & 40 & 49.2 & 52.8 & 60.5 & 66.4 & 70.8 & 75.3 & 77.5 \\
\hline Adult literacy (\%) & 34.6 & 39.6 & 46.4 & 58.3 & 66.9 & 74.4 & 81.4 & 89 \\
\hline \multicolumn{9}{|l|}{ Health } \\
\hline $\begin{array}{l}\text { Number of physicians per } 1,000 \\
\text { population }\end{array}$ & - & - & - & - & 352 & 508 & 1056 & 1256 \\
\hline Maternal mortality ${ }^{5}$ & - & 741 & 752 & 355 & 115.5 & 73.4 & 19 & 10.3 \\
\hline Born at the maternity $(\%)$ & - & - & - & - & 18.4 & 37.5 & 73.8 & 95.5 \\
\hline \multicolumn{9}{|l|}{ Economy } \\
\hline Agricultural sector (\%) & - & 48.2 & 51.4 & 49.4 & 43.3 & 39.7 & 19.4 & 10.6 \\
\hline Industrial sector $(\%)$ & _ & 17.3 & 19.7 & 23.8 & 28.7 & 40 & 38.8 & 37.2 \\
\hline Services $(\%)$ & - & 34.5 & 28.9 & 26.8 & 28 & 20.3 & 41.8 & 50.4 \\
\hline \multicolumn{9}{|l|}{ House conditions } \\
\hline Tap water $(\%)$ & - & - & - & - & 28.9 & 47.4 & 72.4 & 86.8 \\
\hline Shower and bathing tub (\%) & - & - & - & - & 18.6 & 28.7 & 58.2 & 81.8 \\
\hline Sanitary equipment (\%) & - & - & - & - & 41.8 & 58.1 & 79.1 & 88.5 \\
\hline Electricity $(\%)$ & - & - & - & - & 40.5 & 63.8 & 90.7 & 97.7 \\
\hline Sewerage systems (\%) & - & - & - & - & 38.3 & 58.1 & 68 & 90.7 \\
\hline
\end{tabular}

${ }^{1}$ Number of births per 1,000 of population.

${ }^{2}$ Number of children, on average, for each women during their reproductive life (15 - 49 years).

${ }^{3}$ Deaths, from birth to 1 year of life per 1,000 live births.

${ }^{4}$ Deaths, from 1 month to 1 year of life per 1,000 live births.

${ }^{5}$ Deaths per 100,000 women.

*Adapted from Barreto (1996, 2000).

TABLE 2. Estimated total per capita daily energy intake (cal/day) ${ }^{\mathrm{a}}$

\begin{tabular}{|c|c|c|c|c|c|c|c|}
\hline \multirow[b]{2}{*}{ Food } & \multicolumn{7}{|c|}{ Years } \\
\hline & 1963 & 1970 & 1980 & 1985 & 1990 & 1995 & 1997 \\
\hline Cereal and rice & 1,281 & 1,185 & 1,059 & 1,117 & 1,097 & 1,127 & 1,142 \\
\hline Tuber & 226 & 272 & 335 & 319 & 326 & 318 & 294 \\
\hline Sugar & 209 & 279 & 344 & 332 & 335 & 345 & 350 \\
\hline Dry vegetables & 64 & 68 & 34 & 30 & 48 & 41 & 38 \\
\hline Fresh vegetables & 84 & 112 & 48 & 49 & 61 & 62 & 65 \\
\hline Fruits & 156 & 160 & 84 & 96 & 142 & 164 & 172 \\
\hline Meat & 78 & 123 & 197 & 192 & 270 & 312 & 328 \\
\hline Eggs & 14 & 16 & 21 & 25 & 29 & 30 & 30 \\
\hline Milk & 76 & 117 & 140 & 172 & 213 & 227 & 237 \\
\hline Fish & 73 & 95 & 65 & 71 & 79 & 81 & 78 \\
\hline Fats & 407 & 518 & 617 & 687 & 734 & 784 & 788 \\
\hline Alcohol & 172 & 158 & 191 & - & 222 & 208 & 196 \\
\hline Calories & 2,671 & 2,940 & 2,980 & 3,127 & 3,389 & 3,544 & 3,577 \\
\hline Calories $^{\mathrm{b}}$ & 2,843 & 3,098 & 3,093 & - & 3,601 & 3,752 & 3,773 \\
\hline Proteins (gr) & - & - & 87.9 & 92.2 & 108.5 & 115.1 & 116.5 \\
\hline Fats (gr) & - & - & 99.7 & 109.3 & 123.7 & 132.7 & 135.3 \\
\hline $\mathrm{HC}(\mathrm{gr})$ & - & - & 432.9 & 443.7 & 463.5 & 476.6 & 477.9 \\
\hline
\end{tabular}

adapted from Barreto (1996, 2000).

${ }^{\mathrm{b}}$ Calories with alcohol.

In 1972, a program of milk supply for elementary schools was started. The number and percentage of students enrolled and the total number of primary students in Portugal are presented in Table 3. The percentage of students that took advantage of the milk program increased from 1972 to
1986 with the greatest increment in 1975/ 1976.

\section{Secular trend in height}

Figure 2 shows a positive secular trend in height in the 18-year-old Portuguese male 


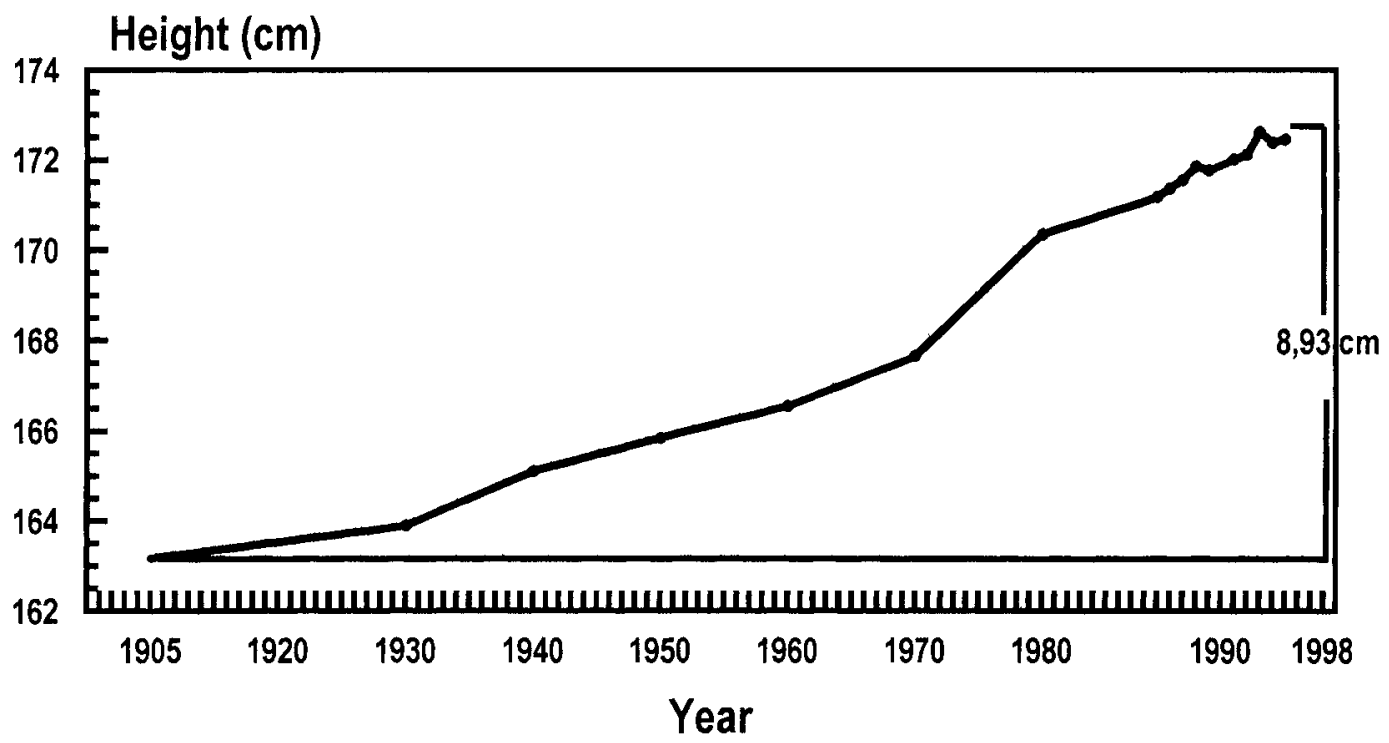

Fig. 2. Secular trend in height of the Portuguese population (1904-1998).

TABLE 3. Program of milk supply in elementary schools $^{\mathrm{a}}$

\begin{tabular}{lccl}
\hline $\begin{array}{l}\text { School } \\
\text { year }\end{array}$ & $\begin{array}{c}\text { Students in } \\
\text { primary class }(N)\end{array}$ & \multicolumn{2}{c}{$\begin{array}{c}\text { Number and \% of } \\
\text { students in the program }\end{array}$} \\
\hline $1972 / 73$ & 970,736 & 22,000 & 2.3 \\
$1973 / 74$ & 946,824 & 37,500 & 4 \\
$1974 / 75$ & 933,112 & 73,000 & 7.8 \\
$1975 / 76$ & 922,204 & 507,000 & 55 \\
$1976 / 77$ & 913,613 & 603,000 & 66 \\
$1977 / 78$ & 925,857 & 704,000 & 76 \\
$1978 / 79$ & 930,754 & 759,000 & 81.5 \\
$1979 / 80$ & 928,992 & 687,800 & 74 \\
$1980 / 81$ & 917,925 & 754,045 & 82.2 \\
$1981 / 82$ & 909,166 & 770,787 & 84.2 \\
$1982 / 83$ & 931,563 & 756,842 & 81.3 \\
$1983 / 84$ & 923,130 & 686,114 & 74.3 \\
$1984 / 85$ & 899,371 & 780,380 & 86.8 \\
$1985 / 86$ & 846,551 & 765,239 & 90.4 \\
$1986 / 87$ & 839,229 & 795,327 & 90.5 \\
\hline
\end{tabular}

${ }^{a}$ Adapted from Henriques and Henriques (1990).

${ }^{\mathrm{b}}$ After this year Madeira and Açores were excluded.

population between 1904 and 1998. Mean height was $163.2 \mathrm{~cm}$ in 1904 and $172.1 \mathrm{~cm}$ in 1998 (Table 4). The average increase was $8.93 \mathrm{~cm}$, which gave an estimated rate of secular increase of $0.99 \mathrm{~cm}$ per decade. Mean increments by district ranged from $6.4 \mathrm{~cm}$ (Santarém) to $11.6 \mathrm{~cm}$ (Bragança). It is clear from Figure 3 that the greatest increments occurred in those districts with the smallest mean height in 1904-Guarda, Castelo Branco, Bragança, Beja, and Portalegre. On the other hand, Aveiro, Santa- rém, and Faro showed the lowest mean increments and had the highest mean heights in 1904.

The increase that occurred in the districts of Portugal between 1904 and 1998 did not present the same pattern during the entire time period. For example, between 1985 and 1998 (Table 4), districts with the greatest increments (Guarda, Viseu, Vila Real, and Braga) were those with the smallest mean heights in 1985. And, the districts with the smallest increments (Madeira, Setúbal, and Lisbon) were those with the highest mean heights in 1985. But, between 1904 and 1985 (Table 4), the highest increments did not specifically occur in those districts with the smallest mean heights. Rather, they occurred in both kinds of districts, those with small mean heights (Portalegre and Beja) and also those with high means (Faro and Lisboa).

\section{Regional differences}

Table 4 and Figure 3 show the mean heights for Portuguese 18-year-old males in each district of Portugal. The mean heights in 1904 are also represented. The earlier data were also obtained from the records of medical examinations at the District Recruiting Centers of Portugal, which implies that the data are comparable. 
TABLE 4. Mean heights of Portuguese 18-year-old males in each district of Portugal in 1904, 1985, and 1998

\begin{tabular}{|c|c|c|c|c|c|c|}
\hline \multirow[b]{2}{*}{ District } & \multicolumn{2}{|c|}{ Examined in $1904^{\mathrm{a}}$} & \multicolumn{2}{|c|}{ Examined in 1985} & \multicolumn{2}{|c|}{ Examined in 1998} \\
\hline & $N$ & Mean & $N$ & Mean $\pm \mathrm{SD}$ & $N$ & Mean $\pm \mathrm{SD}$ \\
\hline Aveiro & 3,509 & 164.1 & 5,404 & $168.1 \pm 6.2$ & 3,209 & $171.9 \pm 6.3$ \\
\hline Beja & 1,834 & 162.3 & 1,597 & $169.8 \pm 6.4$ & 844 & $172.0 \pm 6.4$ \\
\hline Braga & 555 & 163.9 & 7,343 & $168.3 \pm 6.2$ & 5,289 & $172.2 \pm 6.2$ \\
\hline Bragança & 210 & 160.3 & 1,647 & $168.7 \pm 6.1$ & 987 & $172.0 \pm 6.1$ \\
\hline C. Branco & 1.671 & 160.4 & 1.725 & $168.0 \pm 6.1$ & 946 & $171.8 \pm 6.3$ \\
\hline Coimbra & 4,983 & 162.6 & 3,305 & $168.5 \pm 6.4$ & 2,181 & $171.6 \pm 6.3$ \\
\hline Évora & 995 & 164 & 1,405 & $170.1 \pm 6.2$ & 839 & $172.2 \pm 6.2$ \\
\hline Faro & 2,625 & 165 & 2,000 & $170.4 \pm 6.4$ & 1,326 & $172.3 \pm 6.4$ \\
\hline Guarda & 378 & 160.5 & 1,630 & $167.1 \pm 6.4$ & 823 & $171.6 \pm 5.9$ \\
\hline Leiria & 410 & 162.1 & 3,251 & $168.0 \pm 6.1$ & 2,094 & $171.9 \pm 6.5$ \\
\hline Lisboa & 1,319 & 164.2 & 12,860 & $171.6 \pm 6.5$ & 8,014 & $172.8 \pm 6.4$ \\
\hline Portalegre & 410 & 162.3 & 1,167 & $169.5 \pm 6.3$ & 629 & $172.5 \pm 6.2$ \\
\hline Porto & 1,213 & 163.8 & 14,346 & $169.0 \pm 6.4$ & 8,913 & $172.1 \pm 6.3$ \\
\hline Santarém & 1,050 & 164.7 & 3,307 & $169.1 \pm 6.2$ & 1,696 & $171.1 \pm 6.2$ \\
\hline Setúbal & 450 & 164.5 & 2,840 & $171.3 \pm 6.2$ & 1,699 & $172.7 \pm 6.4$ \\
\hline V. Castelo & 1,972 & 163.9 & 2,127 & $168.7 \pm 6.2$ & 1,256 & $172.0 \pm 6.1$ \\
\hline Vila Real & 2,095 & 163.3 & 2,663 & $168.1 \pm 6.2$ & 1,566 & $172.2 \pm 6.1$ \\
\hline Viseu & 2,104 & 162.6 & 4,138 & $167.5 \pm 6.3$ & 2,580 & $171.8 \pm 6.2$ \\
\hline Acores & - & - & 1,801 & $169.6 \pm 6.4$ & 1,469 & $171.6 \pm 6.6$ \\
\hline Madeira & - & - & 2,091 & $169.5 \pm 6.5$ & 1,168 & $169.7 \pm 6.1$ \\
\hline $\begin{array}{l}\text { Total } \\
\text { F }\end{array}$ & 27,783 & 163.2 & 76,647 & $\begin{array}{l}169.2 \pm 6.5 \\
\mathrm{~F}=179.941^{*}\end{array}$ & 47,801 & $\begin{array}{l}172.1 \pm 6.3 \\
\mathrm{~F}=17.95^{*}\end{array}$ \\
\hline
\end{tabular}

aAdapted from Lacerda (1904).

${ }^{\mathrm{b}}$ One way analysis of variance $(\mathrm{F})$ between the 20 districts.

${ }^{*} P \leq 0.001$.

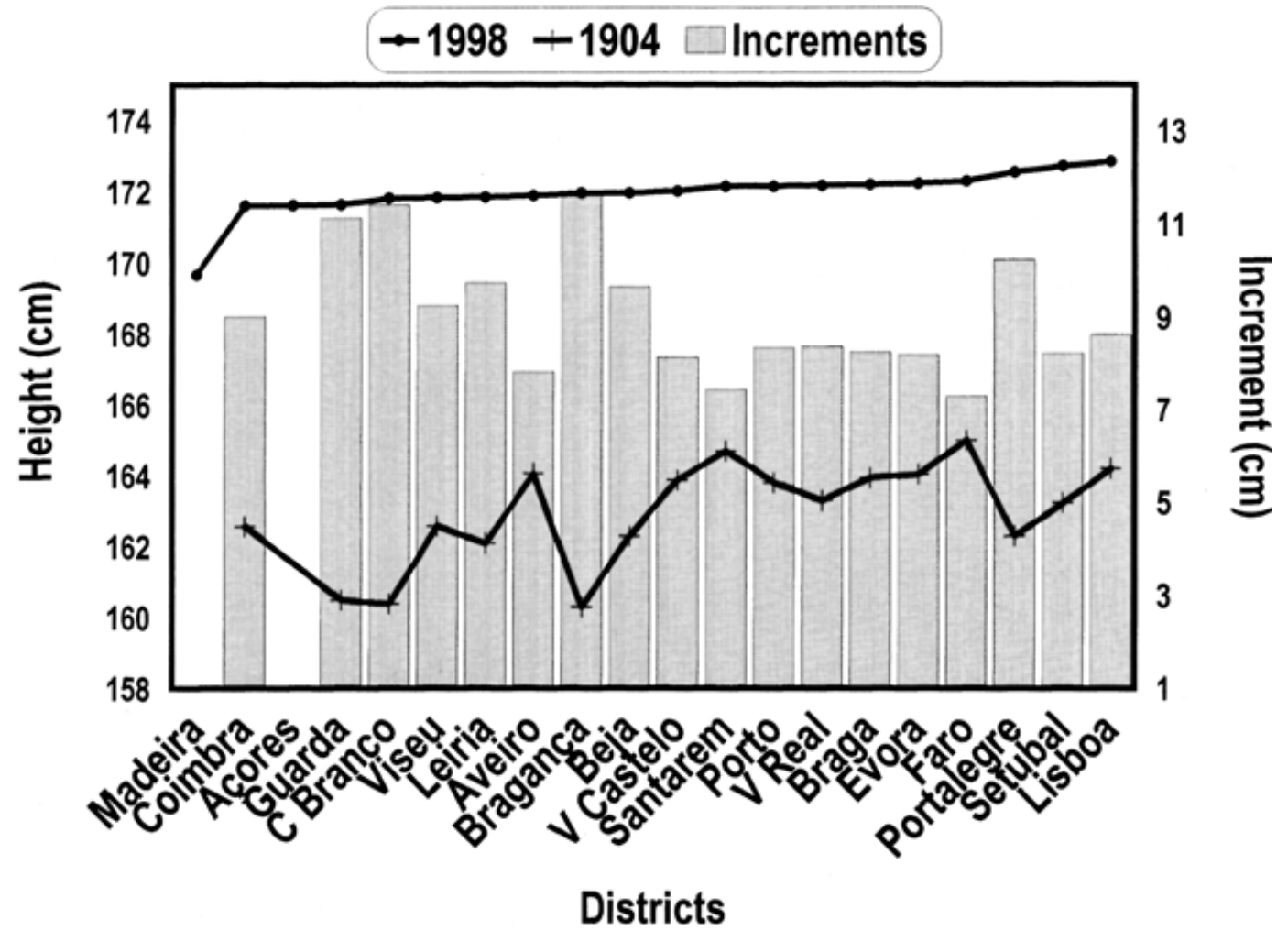

Fig. 3. Mean height of Portuguese 18-year-old males in each district of Portugal in 1904 and 1998. Increments between 1904 and 1998 . 


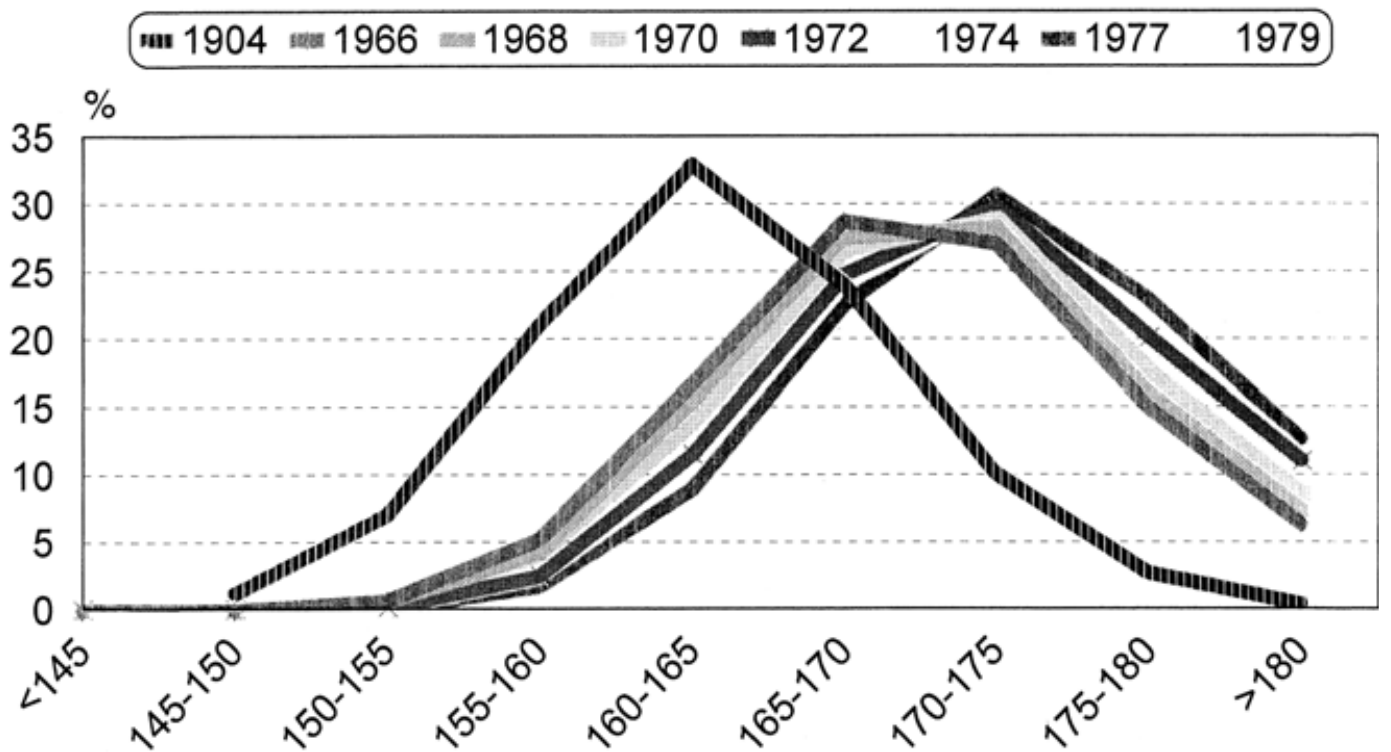

Fig. 4. Stature distribution by classes in 1904, 1985, 1987, 1989, 1991, 1993, 1996, and 1998.

The one way analysis of variance for mean heights shows statistically significant differences among districts in $1985(\mathrm{~F}=$ $179.941, P \leq 0.001)$ and in $1998(\mathrm{~F}=17.95, P$ $\leq 0.001$ ). In 1998, 18-year-old males from Lisbon and Setúbal were tallest, and those from Madeira and Coimbra were shortest. But, the range between the tallest and shortest means was smaller in 1998 (3.16 $\mathrm{cm})$ than in $1904(4.4 \mathrm{~cm})$. Even in 1985, the difference between the tallest and shortest means was somewhat high $(4.45 \mathrm{~cm})$. The present place of residence, which is not an indicator of how long the subjects lived in the same residence was used in the analysis. However, for each district the difference between mean height by residence and place of birth were not statistically significant (data not shown).

\section{Distribution of stature in Portuguese conscripts}

Figure 4 shows the stature distributions in the Portuguese sample in 1904 and in $1985,1987,1989,1991,1993,1996$, and 1998. The distributions have moved to towards higher intervals. In 1904, the class with highest frequency was 160 to $165 \mathrm{~cm}$. From 1985 to 1998, there were two different periods with a shift. The first, from 1985 and 1989, showed two prevalent classes,
165 to $170 \mathrm{~cm}$ and 170 to $175 \mathrm{~cm}$, and the second from 1993 until 1998, the most prevalent class was 170 to $175 \mathrm{~cm}$. The Kolmogorov-Smirnov test showed that from 1985 to 1998 , height showed a normal distribution in each year.

\section{DISCUSSION}

This study of secular trend in Portugal showed a positive increment in height in Portuguese 18-year-old males between 1904 and 1998. The overall increase in this period was $8.93 \mathrm{~cm}$ or an estimated rate of 0.99 $\mathrm{cm}$ per decade. This increment is similar to average rates of secular increase in adult heights that occurred during this century in most western and industrialized countries, 0.3 to $3.0 \mathrm{~cm} /$ decade (Eveleth and Tanner, 1990; Hauspie et al., 1996). At present, the average final height is $172.13 \mathrm{~cm}$. Despite this increase Portuguese males are the shortest in Europe. The most recent published data indicate the following mean heights of young adult males: Spain, 173.8 cm (Rebato, 1998); France, 174.9 cm (Pineau, 1993); Belgiun, $176.8 \mathrm{~cm}$ (Vercauteren, 1993); Bulgaria, $173.6 \mathrm{~cm}$ (Stoev and Yordanov, 1998); Czech Republic, $178.84 \mathrm{~cm}$ (Vignerová and Bláha, 1998); Austria, 177.5 cm (Weber et al., 1995); England, $175.7 \mathrm{~cm}$ 
(Rosenbaum et al., 1985); Poland, $176.7 \mathrm{~cm}$ (Bielicki and Waliszko, 1991); Greece, 177.6 cm (Manolis et al., 1995); Hungary, 178.5 cm (Gyenis, 1997); Sweden, $179.5 \mathrm{~cm}$ (Tuvemo et al., 1999); and The Netherlands, 184 cm (Fredriks et al., 2000).

As in almost all other countries, the estimated rate of secular increase is not constant during the overall period. Taking into account the present results for 1998 and those published by Sobral (1990) just for the same districts (Lisboa, Setúbal, Évora, and Beja for 1930-1980), the following rates are estimated: $1.21 \mathrm{~cm}$ for 1930 to 1940; $0.74 \mathrm{~cm}$ for 1940 to $1950 ; 0.7 \mathrm{~cm}$ for 1950 to $1960 ; 1.11 \mathrm{~cm}$ for 1960 to $1970 ; 2.7$ $\mathrm{cm}$ for 1970 to $1980 ; 1.68 \mathrm{~cm}$ for 1980 to 1990; and $2.09 \mathrm{~cm}$ for 1990 to 1998 . The comparison suggests that the highest rates occurred between the 1970s and 1980s. Variability in rates was also reported in other countries such as Poland $(2.4 \mathrm{~cm}$ in 1965-1976, $2.1 \mathrm{~cm}$ in 1976-1986, and 1.8 between 1986-1995; Bielicki and Szklarska, 1999), in Croatia (3 cm in 1951-1964, $0.6 \mathrm{~cm}$ in $1964-1973,2.5 \mathrm{~cm}$ in $1973-1982$, and $0.6 \mathrm{~cm}$ in 1982-1991; Prebeg et al., 1995), in Austria (0.8 cm for birth years $1962-1966$ and $1.3 \mathrm{~cm}$ for $1972-1975$; Weber et al., 1995), in Italy $(6.4 \mathrm{~cm}$ in $1874-1951$ and $2.6 \mathrm{~cm}$ in $1951-1960$; Ullizi and Terrenato, 1982), in The Netherlands $(2.7 \mathrm{~cm}$ in $1955-1965,2.0 \mathrm{~cm}$ in 1965-1980, and $1.3 \mathrm{~cm}$ in 1980-1997; Fredriks et al., 2000), in the Czech Republic $(0.9 \mathrm{~cm}$ in $1951-1961,2.08 \mathrm{~cm}$ in $1961-1971,1.77 \mathrm{~cm}$ in 1971-1981, and $0.69 \mathrm{~cm}$ in 1981-1991; Vignerová and Bláha, 1998), in Spain (1.4 $\mathrm{cm}$ in 1960-1970, $3.2 \mathrm{~cm}$ in 1970-1980, and $2.5 \mathrm{~cm}$ in 1980-1990; Rebato, 1998), and in Hungarian university students $(1.49 \mathrm{~cm}$ in 1976-1985 and $0.89 \mathrm{~cm}$ in 1986-1990; Gyenis, 1997).

There are limited comparative data for stature distributions: there is a similar pattern in the Portuguese population compared with Spain (Hernández and GarcíaMoro, 1986), Italy (Chamla, 1983), and France (Chamla, 1983; Pineau, 1993). Height classes to $170 \mathrm{~cm}$ decreased in frequency and classes $\geq 170 \mathrm{~cm}$ increased in frequency. On the other hand, populations like Belgium (Chamla, 1983), Denmark (Chamla, 1983), The Netherlands (Chamla, 1983), Norway (Chamla, 1983), and Sweden (Chamla, 1983) showed a decrease in the lowest classes until $175 \mathrm{~cm}$ or even until
$180 \mathrm{~cm}$ and an increase of the higher classes.

The overall positive secular trend in height in young adult Portuguese males was associated with larger increases in those districts that were the shortest in 1904 , a decrease in the frequency of the lowest classes of stature $(<170 \mathrm{~cm})$, and an increase of the frequency in the highest classes $(\geq 170 \mathrm{~cm})$. These represent the general improvement in living conditions that occurred in Portugal after the 1970s. Bragança, C. Branco, Guarda, and Portalegre, some of the more inland districts, were the shortest in 1904 but had the highest increments between 1904-1998, reaching increases of $11.7,11.4,11.1$, and $10.3 \mathrm{~cm}$, respectively. On the other hand, Aveiro, Santarém, and Faro, which were the tallest in 1904, had the lowest increments between 1904 to 1998 (7.8, 6.5, and $7.3 \mathrm{~cm}$, respectively). Portugal is an ethnically highly homogeneous population with no national, linguistic, religious, or racial minorities. Recent findings in human genetics (ArnaizVilhena et al., 1997; Pereira et al., 2000) attested this. Thus, it may be concluded that the height differences most likely reflect differences in living standards. This was also found in almost countries in Europe. In the Belgian population, Vercauteren (1993) found that university students, from families of above-average socioeconomic status, had the smallest increment in height $(0.5 \mathrm{~cm} /$ decade $)$ than conscripts representing the total population $(1.6 \mathrm{~cm} / \mathrm{de}$ cade). In France, Demoulin (1998) noted that the greatest increase was found in the departments where mean stature was initially short. The 10 departments with the smallest $(<3 \mathrm{~cm})$ increment between 1880 to 1960 showed the highest increase of mean stature between 1960 and 1989 (on average $5.8 \mathrm{~cm})$. By contrast, the 10 departments with the highest increment $(>6 \mathrm{~cm})$ in 1880 to 1960 displayed the smallest increase of height $(3.8 \mathrm{~cm})$ between 1960 and 1989 . Similar findings were reported by Rebato (1998) in Spain. Regions that started with small mean sizes (Galicia, Andalusia, Extremadura, and both Castilles) had the highest absolute increase $(5-6 \mathrm{~cm}$ from 1965-1985), in contrast with the increase recorded in regions of traditionally taller stature (Basque country $<4 \mathrm{~cm}$; Cantabria and Catalonia, 4-5 cm). Similar results were reported for the Austrian population 
(Weber et al., 1995). Between 1962 and 1975, 18-year-old Austrian males from urban areas increased in height by only 0.1 $\mathrm{cm} /$ decade, while peers from rural areas increased in stature of $0.8 \mathrm{~cm} /$ decade during the same period. A different pattern was noted in the Polish population. In two large samples of conscripts 19 years of age, examined in 1965 and 1995, a secular increase in height occurred in all socioeconomic groups but was greatest for the upper social group (Bielicki et al., 1981; Bielicki and Waliszko, 1991).

Socioeconomic factors do not influence growth directly but act through biological factors such as nutrition and infection, both of which may influence growth (Sandberg and Steckel, 1987; Floud, 1994; Floud et al., 1990). The Portuguese nutritional pattern changed between 1960 and 1997. Some products, like milk, meat, eggs, sugar, proteins, and fats, increased considerably. In other populations like Italy, Ullizi and Terrenato (1982) stressed the importance of these dietary components on the secular trend on Italian conscripts born from 1874 to 1960. Another example is the Japanese population. Takahashi (1984) linked the secular trend in height in Japan to the consumption of milk, which has risen steeply since the World War II and concluded that milk consumption among the younger generation was one of the most important causes of the acceleration of growth in height. In Portugal, besides the increase in milk consumption in the general population, a program of milk supply in elementary schools started in 1972/1973 and increased especially after $1975 / 1976$. It is suggested by Bogin $(1998,1999)$ that milk is an important component that positively influences growth. Another important element is sugar consumption, which increased from 209 to $350 \mathrm{cal} /$ day between 1963 and 1997 in the Portuguese population. Ziegler (1967) and Froment (1986) suggest that the increase in sugar consumption has implications for the secular trend because refined sugars provide more rapidly accessible energy.

The Portuguese health system had many improvements, mainly after the 1970s. This was reflected in a decrease in post-neonatal mortality, an increase in life expectancy, and improvement in other indicators such as the number of physicians per 1,000 population, and the percentage of infant born at maternity centers. The post-neonatal mortality rate is generally regarded as a sensitive indicator of infant health (Kessel, 1990), and infant nutritional status and the prevalence of infections are the most important determinants of post-neonatal mortality (Stembera, 1990). These trends are consistent with those reported by Schmidt et al. (1995) for several European countries. Height increased toward a maximum when post-neonatal mortality approached zero. The authors speculated that adult height in middle and southern European countries will continue to increase for approximately 2 decades after post-neonatal mortality reached a low and stable level at approximately 3 to 5 per 1,000 newborns. Viewed in this perspective, it would be expected that the mean height of young adult Portuguese would increase in the future decades.

The heights of young adults reflect the nutritional status of the population approximately 15 to 20 years before recruitment. Many studies suggested that adverse environmental factors have their strongest effect during childhood (Cole, 2000; Nystrom Peck and Lundberg, 1995; Nystrom Peck and Vagero, 1987; Wadsworth, 1997; Brundtland et al., 1980; Schmidt et al., 1995; Tanner, 1992). The subjects of the present study were born between 1966 to 1979. If their birth period is paired with changes associated with nutrition, the health system, and socioeconomic development, the results suggest that they were perhaps the first to take advantage of these improvements.

In a country as small as Portugal, there are regional differences in observed secular changes. The differences are most prominent between the inland and the littoral districts. In fact, these districts located more inland (Guarda, C. Branco, and Viseu) are still among the shortest mean heights. These are also the districts where population size has decreased during this century, post-neonatal mortality rates are high, and the percentage of older people ( $>65$ years) is high (Barreto, 1996, 2000). Nevertheless, although there were significant differences among districts in 1998, the range between the tallest and shortest males is now smaller $(3.2 \mathrm{~cm})$ than in $1904(4.4 \mathrm{~cm})$. The difference between the tallest and the shortest mean heights was high $(4.5 \mathrm{~cm})$ in 1985, which suggests that the secular 
changes are rather recent. Data on secular change in the maturity of males are not available, but age at menarche decreased from 15 years in 1880 to 1890 to 12.4 years in 1980 (Rocha et al., 1998). Corresponding changes can be assumed in the male population. This implies that recruits in 1904 probably did not achieve their final height at 18 years. It should be noted, however, that Lacerda (1904) added $1 \mathrm{~cm}$ to the height values to avoid this problem.

In summary the results demonstrate a positive secular increase in young adult height in Portuguese males, which is similar to that occurring in other European countries. The changes indicate a decrease in the shortest classes and an increase in the highest classes of stature. Socioeconomic changes in Portugal, especially in terms of nutrition and health system, are important underlying factors.

\section{LITERATURE CITED}

Arnaiz-Villena A, Martínez-Laso J, Gómez-Casado E, Díaz-Campos N, Santos P, Martinho A, Breda-Coimbra H. 1997. Relatedness among Basques, Portuguese, Spaniards, and Algerians studied by HLA allelic frequencies and haplotypes. Immunogenetics 47:37-43.

Barker DJP, Osmond C, Golding J. 1990. Height and mortality in the counties of England and Wales. Ann Hum Biol 17:1-6.

Barreto A. 1996. A Situação Social em Portugal, 1960-1995. Lisboa. Instituto de Ciências Sociais, Universidade de Lisboa.

Barreto A. 2000. A Situação Social em Portugal, 1960-1999, Volume II. Lisboa. Instituto de Ciências Sociais, Universidade de Lisboa.

Bielicki T, Szczotka H, Charzewski J. 1981. The influence of three socio-economic factors on body height in Polish military conscripts. Hum Biol 53:543-555.

Bielicki T, Waliszko H. 1991. Urbanization-dependent gradients in stature among Polish conscripts in 1976 and 1986. Am J Hum Biol 3:419-424.

Bielicki T, Malina R M, Waliszko H. 1992. Monitoring the dynamics of social stratification: statural variation among Polish conscripts in 1876 and 1986. Am J Hum Biol 4:345-352.

Bielicki T, Szklarska A. 1999. Secular trends in stature in Poland: national and social class-specific. Ann Hum Biol 26:251-258.

Bodzsár EB, Susanne C. 1998. Patterns of secular change of growth and development. In: Bodzsár EB, Susanne C, editors. Secular Growth Changes in Europe. Budapeste: Eotvos University Press. p 5-26.

Bogin B.1998. Milk and human development: an essay on the "milk hypothesis". Antropol Port 15:23-36.

Bogin B. 1999. Patterns of Human Growth, $2^{\text {nd }}$ edition. Cambridge: Cambridge University Press.

Brundtland GH, Liestol K, Walloe L. 1980. Height, weight and menarcheal age of Oslo school children during last 60 years. Ann Hum Biol 7:307-322.

Carrion JMM. 1986. Estatura, nutrition y nivel de vida en Murcia, 1860-1930. Rev Hist Econ IV:67-99.
Chamla MCl. 1983. L' Evolution recente de la stature en Europe Occidentale (Période 1960-1980). Bull Mém Soc D' Anthrop Paris 10:195-224.

Chinn S, Rona RJ, Price CE. 1989. The secular trend in height of primary school children in England and Scotland 1972-79 and 1979-86. Ann Hum Biol 16:387-395.

Cole TJ. 2000. Secular trends in growth. Proc Nutr Soc 59:317-324.

Demoulin F. 1998. Secular trend in France. In: Bodzsár EB, Susanne C, editors. Secular Growth Changes in Europe. Budapest: Eotvos University Press. p $109-134$.

Eveleth PB, Tanner JM. 1990. Worldwide Variation in Human Growth, 2nd edition. Cambridge: Cambridge University Press.

Floud R. 1994. The Heights of Europeans since 1750: a new source for European economic history. In: Komls J, editor. Stature, Living Standards, and Economic Development: Essays in Anthropometric History. Chicago: The University of Chicago Press.

Floud R, Wachter K, Gregory A. 1990. Height, Health and History. Cambridge: Cambridge University Press.

Fogel RW, Engerman SL, Trussel J. 1982. Exploring the uses of data on height: the analysis of long-term trends in nutrition, labor welfare and labor productivity. Soc Sci Hist 6:401-581.

Fredriks AM, Van Buuren S, Burgmeijer RJF, Meulmeester JF, Beuker RJ, Brugman E, Roede MJ, Verloove-Vanhorick SP, Wit J-M. 2000. Continuing positive secular growth change in The Netherlands 1955-1997. Ped Res 47:316-323.

Froment A. 1986. Aspects nutritionnels de l'anthropologie. In: Ferembach D, Susanne, C, Chamla C, editors. L'Homme, son évolution, sa Diversité. Doin: Paris. p 347-357.

Gyenis G. 1997. Continuing positive growth changes in height and weight of Hungarian University students. Ann Hum Biol 24:475-479.

Hauspie RC, Vercauteren M, Susanne C. 1996. Secular changes in growth. Horm Res 45[Suppl. 2]:8-17.

Henriques R, Henriques T. 1990. A Produção e a Industrialização do Leite em Portugal. Nova Agricultura Lisboa. Edições Afrontamento.

Hermanussen M, Burmeister J, Burkhardt V. 1995. Stature and stature distribution in recent West German and Historic samples of Italian and Dutch conscripts. Am J Hum Biol 7:507-515.

Hernández M, García-Moro C. 1986. Cambios antropométricos recientes en poblacion masculina Española. Trab Antropol 20:3-14.

Kessel SS. 1990. Postneonatal mortality: a performance indicator of the child health care system. Pediatrics $86: 1107-1111$.

Lacerda J. 1904. Estatura do Português Adulto. Dissertação para a cadeira de Antropologia (Manuscrito). Coimbra: Universidade de Coimbra.

Laska-Mierzejewska T, Milicer H, Piechaczek H. 1982. Age at menarche and its secular trend in urban and rural girls in Poland. Ann Hum Biol 9:227-233.

Low WD, Kung LS, Leong JC. 1982. Secular trend in the sexual maturation of Chinese girls. Hum Biol 54:539-551.

Low WD, Kung LS, Leong JC, Hsu L, Fang D, Yan AC, Lisowski FP. 1981. The secular trend in the growth of southern Chinese girls in Hong Kong. Z Morphol Anthropol 72:77-88.

Malina RM. 1979. Secular changes in growth, maturation, and physical performance: secular trends in human growth, maturation and development. Mon Soc Res Child Dev 44:59-120. 
Manolis S, Neroutsos A, Zafeiratos C. 1995. Secular changes in body formation of Greek students. Hum Evol 10:199-204

Nystrom Peck M, Lundberg O. 1995. Short stature as an effect of economic and social conditions in childhood. Soc Sci Med 41:733-738.

Nystrom Peck M, Vagero DH. 1987. Adult body height and childhood socioeconomic group in the Swedish population. J Epidemiol Comm Health 41:333-337.

Pereira L, Prata MJ, Amorim A. 2000. Diversity of mtDNA lineages in Portugal: not a genetic edge of European variation. Ann Hum Genet 64:491-506.

Pineau JC. 1993. La stature en France depuis un siécle: évolution générale et régionale. Bull Mém Soc d'Anthropol Paris 5:257-268.

Prebeg Z, Juresa V, Kujundzic M. 1995. Secular growth changes in Zagreb schoolchildren over four decades, 1951-91. Ann Hum Biol 22:99-110.

Rebato E. 1998. The studies on secular trend in Spain: a review. In: Bodzsár EB, Susanne C, editors. Secular Growth Changes in Europe. Budapest: Eotvos University Press. p 297-317.

Rocha MA, Padez C, Xavier de Morais MH. 1998. Urbanização e idade da menarca na população portuguese: evolução secular (1880-90 a 1980). Antropol Port 15:59-75.

Rosenbaum S, Skinner RK, Knight IB, Garrow JS. 1985 A survey of heights and weights of adults in Great Britain. Ann Hum Biol 12:115-127.

Sandberg LG, Steckel RH. 1987. Heights and economic history: the Swedish case. Ann Hum Biol 14:101-110.

Schmidt IM, Jorgensen MH, Michaelsen KF. 1995 Height of conscripts in Europe: is postneonatal mortality a predictor? Ann Hum Biol 22:57-67.

Sobral F. 1990. Secular changes in stature in southern Portugal between 1930 and 1980 according to conscript data. Hum Biol 62:491-504.

Stembera Z. 1990. Prospects for heights infant survival. World Health Forum 11:78-84.

Stoev R, Yordanov Y. 1998. Secular trend in Bulgaria In: Bodzsár EB, Susanne C, editors. Secular Growth Changes in Europe. Budapeste: Eotvos University Press. p 65-73.
Susanne C, Heyne D. 1972. Stature, poids et capacité vitale des étudients et étudients de l'Université Libre de Bruxelles. Bull Soci Royal Belge d'Anthropol Préhistoire 83:101-105.

Takahashi E. 1984. Secular trend in milk consumption and growth in Japan. Hum Biol 56:427-437.

Tanner JM. 1986. Growth as a mirror of the conditions of society: secular trends and classifications. In: Demirjan A, Brauit Dubuc, M, editors. Human Growth: A Multidisciplinary Review. London/Philadelphia: Taylor and Francis. p 3-34.

Tanner JM. 1992. Growth as a measure of the nutritional and hygienic status of a population. Horm Res 38(Suppl):106-115.

Tuvemo T, Jonsson B, Persson I. 1999. Intellectual and physical performance and morbidity in relation to height in a cohort of 18-year-old Swedish conscripts. Horm Res 52:186-191.

Ulizzi L, Terrenato L. 1982. A comparison between the secular trends of stature and some socio-economic factors in Italy. J Hum Evol 11:715-720.

van Wieringen JC. 1986. Secular growth changes. In: Falkner F, Tanner JM, editors. Human Growth. New York: Plenum Press. p 307-331.

Vercauteren M. 1993. Croissance, facteurs socio-familieux et évolution séculaire. Bull Mém Soc d'Anthopol Paris 5:85-92.

Vercauteren M, Slachmuylder JL. 1993. Croissance d'enfants belges en milieu urbain (Bruxelles) et rural (Viroinval). Anthropol Préhist 104:151-161.

Vignerová J, Bláha P. 1998. The growth of the Czech child during the past 40 years. In: Bodzsár EB, Susanne C, editors. Secular Growth Changes in Europe. Budapest: Eotvos University Press. p 93107.

Waaler H. 1984. Height, weight and mortality: the Norwegian experience. Acta Med Scan 679(Suppl):1-56.

Wadsworth MEJ. 1997. Health inequalities in the life course perspective. Soc Sci Med 44:859-869.

Weber G, Seidler H, Wilfing H, Hauser G. 1995. Secular change in height in Austria: an effect of population stratification? Ann Hum Biol 22:277-288. 